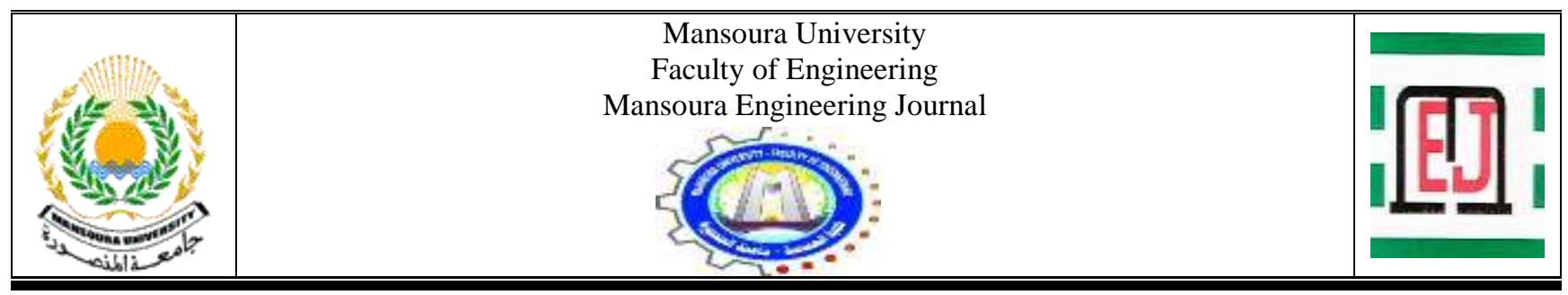

\title{
Reimaging Streets: A Design Approach for Enhancing Walkability in Old Cities Case Study: El Gomhouria Street, Mansoura
}

\begin{tabular}{|l|}
\hline KEYWORDS: \\
Walkability, Reimaging \\
Urban Environment, \\
Urban Design Qualities \\
\\
\end{tabular}

\author{
Ahmed Mohamed Thabet
}

\begin{abstract}
Designing cities for cars rather than people has left them unhealthy, and has left many streets unattractive places to walk, cycle or use public transport. Roads become more crowded and cities become congested. In the last two decades, creating walkable cities becomes a different vision of recent urban design approaches. Walkable cities means that they have quality spaces to thrive, safe, and inviting to people of all ages to be capable of reaching every inch of the spaces by walking. Walkable places are comfortable, convenient, healthy, and sustainable, places where people can get chances to meet each other or to have potential outdoor activities. However, obtaining walkable cities in Egypt is still a challenge because of its difficulty to achieve. Therefore, the time has come for more effective urban design approaches seeking enhancing walkability in Egyptian cities. The objective of this research is to present a design approach for enhancing walkability in congested and car-dependent cities such Egyptian cities. The main core of the proposed deign approach is based on reimaging the physical elements and upgrading the aesthetics and visuals of the built environment to attract people to mainly depend on walking as a means of transportation. .
\end{abstract}

\section{INTRODUCTION}

I $\mathrm{N}$ the last few decades, Egypt has witnessed the negative consequences of a built environment that no longer caters to the pedestrian, where a growing dominance of the automobile has guided development and growth of Egyptian cities. A drastic lack of pedestrian-friendly conditions in urban spaces is unquestionably present [1]. Most of the planning, public health, and transportation experts becomes concentrating on how to transform large scale communities to healthy, safe, and vibrant spaces for people by trip degeneration and reduction of depending on motorized

Received: (10 March, 2021) - Revised: (27 April, 2021) - Accepted: (11 April, 2021)

Corresponding Author: Dr. Ahmed Mohamed Thabet, Assistant professor at the Department of Architecture, Faculty of Fine Arts, Mansoura University (e-mail: ahmedm.thabet@mans.edu.eg ). transport [2]. They adopted Remarkable solutions instead of depending on motorized transport such as diverse mix of landuse, mixed-use areas, residential compounds, larger sidewalks, smaller blocks, and continuous networks of streets, and opened the doors to investigate the relationship between the built environment and physical activity, and later, walkability [3]..

Omar, et al., [4] mentioned that the concept of walkable communities is like the concept of getting back the vibrance of streets by the presence of people walking and interacting at their level. In urban spaces, the strong relationship between the urban built environment and pedestrian reflexes the behavior and perception of them about how using walkways. Moreover, Marino [5] said that a walkable city has multiple and significant social, economic, environmental, and even political benefits. When cities struggle to reduce cardependent movement, the community can be safer, healthier, and more vibrant for residents and visitors. People's intendance to walk in urban spaces depends on safety and 
feasibility of walkways inside them [6]. Therefore, as shown in Pic. 1, urban design should be a catalyst to this tendency by reimaging the urban public spaces in a way affecting users' behavior and changing the shape and mode of their daily movement [4].

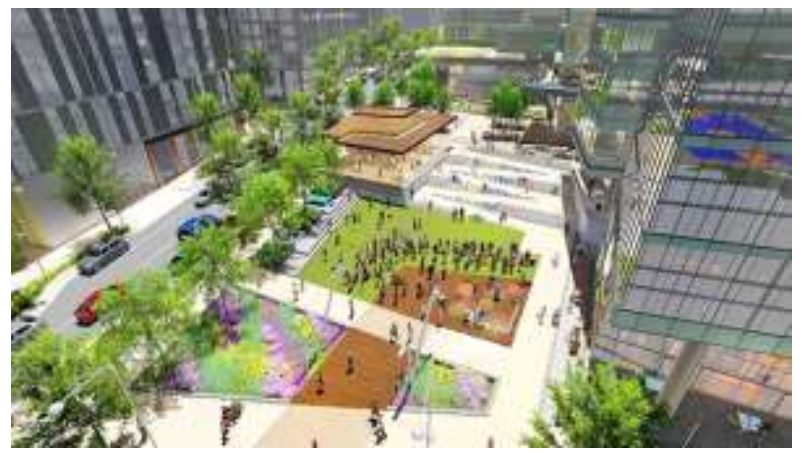

Pic. 1. Urban design solution encouraging walkability, Canada [5]

The term walkability is derived from the word "walk" and presents the rate and possibility of walking by people in a certain area [7]. Reagan [3] mentioned that walking is the first activity that infants struggle to do and the last one that oldies like to give up. As a vital human process, walking was the cause of the origin of the early human history and its changes over time [3]. Walking is very important activity for the human being because it is a mode of transportation equivalent to other motorized modes such as cars and trains [7, 8]. Walking is the cheapest and the healthiest means of transport that all categories of people can use. Furthermore, walking is the exercise that can be practiced for free. People can control their weight and maintain their health provided that they keep a sufficient amount of walking on a daily basis. Nevertheless, until recently little interest is given for the research on walking behavior and environments [4].

Chris Bradshaw attempted to physically assess the term walkability by setting the comprehensive definition combining several characteristics. He described it as man-made, footfriendly, and physical micro-environment with comfortable sidewalks, small intersections, good lighted, and feasible with any obstructions, Pic. 2. Moreover, walkability is growing when a full range of active and interesting destinations containing services, shops, and many recreational facilities in a natural environment are encouraging users to walk. All these characteristics may be created in a socially diverse manner increasing the contact between people and the physical features of the are they pass by [4]. Omar, et al. [4] has explained in details the terms related to walkability; he said that walkability is the state to which the urban environment is pedestrian friendly; walkable means the capability of being crossed, traveled by walking in a smooth way, and prompting physical activity in a safe, beautiful, friendly, and barrier free walkways; and pedestrian access is the capability of reaching to a certain urban area by foot.

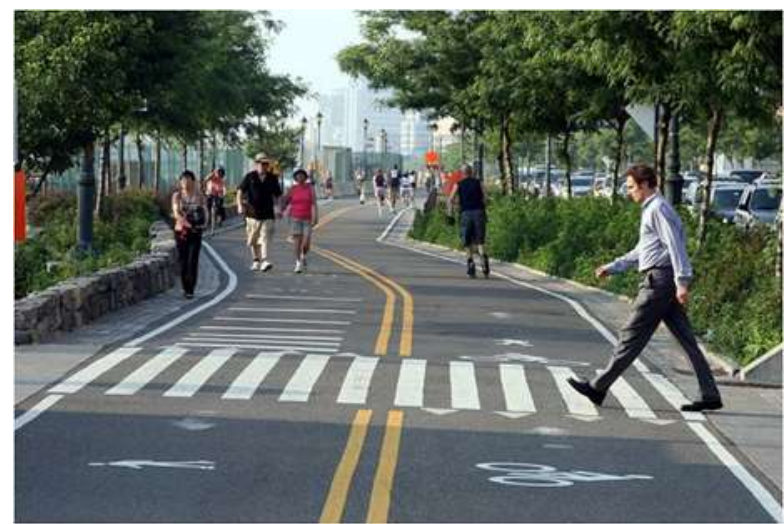

Pic. 2. Urban design solution encouraging walkability, Germany [9]

Pedestrian-based design has many benefits for both humans and the environment; Marino [5] said that this can decrease pollution levels in urban environments by reducing Carbone dioxide emotions, numbers of cars, and as a sequence the intensity of greenhouse and heat island effects. Moreover, Omar, et al., [4] and Reagan [3] added that it can reduce maintenance costs, and the costs of constructing roadways and providing parking areas for local governments. Furthermore, walkability can increase the social interaction between inhabitants and this can reduce crime and enhance the social identity [5] . Therefore, studies have focused on how to develop the built environments to enhance this demand. Walking and biking as active transportation can provide healthier residents who are lower risk of obesity, heart disease, censers, or chronic disease; depending on active transportation is as effective as regular physical and mental health workout $[3,10]$.

Omar, et al., [4] mentioned that a big distance between two points, the lower quality pedestrian infrastructure, and the lack of leisure possibilities are the causes of why people dislike walking more in urban spaces. According to Reagan [3], the lack of reliance on walking in urban communities has led to negative health impacts such as increasing heart disease and obesity, which required the need for walkability. Nevertheless, there was a lack of the understanding of how to achieve walkability, and then most trials have failed. Streets should be understanded as public spaces in which people can spend their everyday lives [3]. Irvin [11] sated that the mutual relationship between streets and people is a vital element that should be taken into consideration to achieve walkability. Moreover, the negative impact of car-oriented making barrier between people in urban spaces, and the everyday killed and injured pedestrians shed the light on the demand of satisfying the human scale dimension in new urban designs $[5,11]$.

By the year of 2020, the covid-19 pandemic has dominated all things in all over the world. The whole world has adopted many precautionary procedures to fight infection to prevent the spread of the corona virus. The core procedure of them is to maintain the appropriate physical distances between people and to depend on the existence outdoors instead of indoors to avoid infection as possible [12]. According to LiuID, et al., [13], due to its collective attitude, its lower fare, and its importance for the broad classes of people, public transit is a vital mode of transportation on which many governments depend on to provide transportation systems. With returning to life after lockdown, many people are deeply anxious about being in crowded places such as 
train, metro and bus stations for fear of infection [14]. Therefore, walking with the precautionary procedures against covid-19 will be a clean and safe means of transportation, and the enhancement of walkability will be an essential demand for keeping communities safe [14, 15].

El-zemrany and Kandil [1] mentioned that more than half of the world's population is attracted to live in city central districts because they provide good conditions to live, work, and doing business. Metropolitan cities such as Mansoura in Egypt, the population density is growing continuously, and the boundaries of the city are heavily and spontaneously expanding to absorb the increasing number of populations, and to alleviate the congestion in the city centers, shown in Pic. 3 [16]. This urban expansion demands caused increasing and complex travel patterns between districts with a strong dependence on private vehicles and other motorized means of transports. The city suffers from a decline in its built environment that caused depression to the pedestrian in the street that made their attention to walk became much less. Egyptian citizens consider motorized means of transport especially private cars - an urgent need to fulfill their movements between sprawling portions or even proximal inside their cities [1].

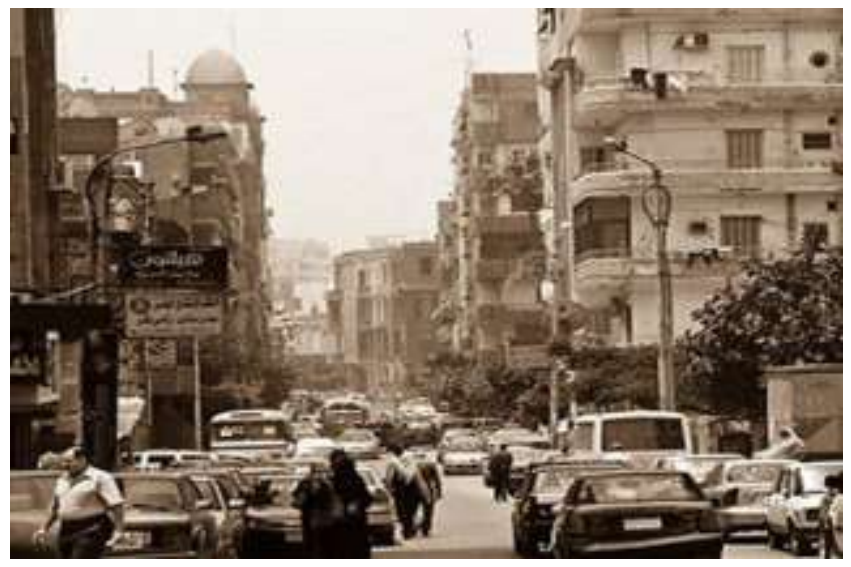

Pic. 3. Crossing the road can be a matter of life or death, Mansoura, Egypt. [17]

Many Egyptian cities like Mansoura have many deficiencies in pedestrian infrastructure, shown in Pic. 4 [16]. Reagan [3] mentioned that the streets are in most cases carfocused and without pedestrian facilities such as safe sidewalks and enabled crosswalks connecting major destinations. El-zemrany and Kandil [1] said that these streets lack many elements encouraging people to walk, such as recreational facilities, well paved walkways, green areas, plazas, and other streetscape elements that improve the image of the walking area, and make it more attractive and comfortable for walking. In this context, providing a design approach for reimaging the urban environment of the Egyptian city may increase its level of walkability; investigating people's perception of walkability systems can introduce several guidelines to improve their orientations and behaviors concerning the culture of walking in their surrounding urban environments [18-20].

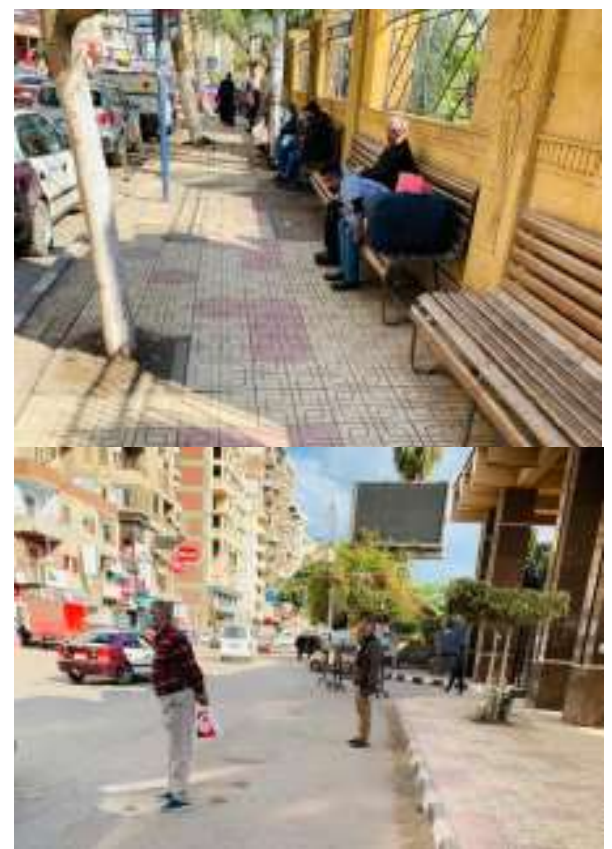

Pic. 4. Deficiencies in pedestrian facilities in Mansoura. The author

\section{RESEARCH HYPOTHESIS AND QUESTIONS}

Urban design concentrating on reimaging streets may give a good start to change people culture and improve their behavior related to walking more in their surrounding environment. Being pedestrianized is the easiest way to solve the problems of traffic congestion and to push people to get more activity and to enhance their physical and mental health [21]. However, this cannot be easily achieved in Egyptian congested cities like Mansoura; the existing pedestrian facilities in these cities may not be able to provide safe and enjoyable walking and cycling pathways. Furthermore, cities supporting walkability are more economically, healthier with lower air and noise pollution rates, and with reduced road deaths and injuries; when people walk more, traffic problems go down, and health and the quality of life improve. In this context, the main hypothesis of this research is that creating attractive places by focusing on improving the aesthetics and visuals of their physical contents could positively change people's decision to walk as a mode of transport, shown in Fig. 1. The research is going to answer the following questions to achieve the main hypothesis:

1. How do the physical characteristics of urban spaces affect their potential walkability?

2. How does the image of the streets affect people's decision to walk as a mode of transportation?

3. How can reimaging the streets be an effective design approach enhancing walkability in cities?

4. How will the citizens of Mansoura perceive their city after reimaging its streets? To what level will their desire to walk improve?

5. How can urban spaces in Egypt be converted to be walkable places? Can pedestrianized urban spaces be created without side effects in Egypt? 


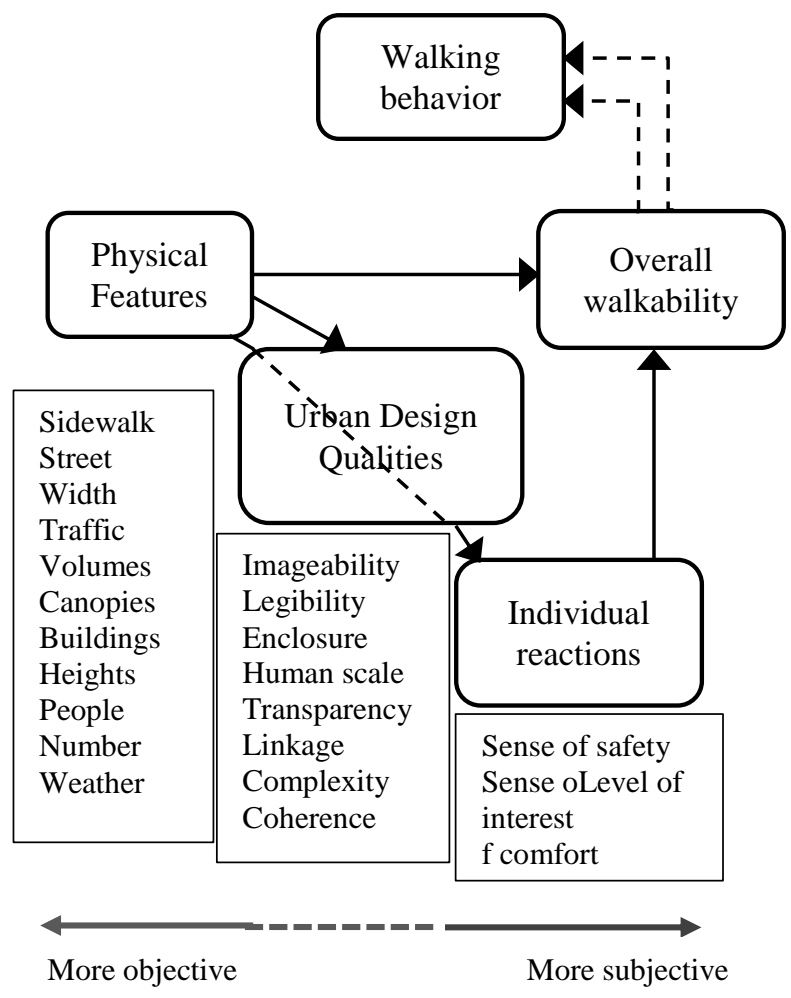

Fig. 1. The main research hypothesis. Derived from [17]

\section{Materials And MethodS}

The research is mainly depending on the information obtained from a framework proposed by Ewing and Handy [22] which concentrates on measuring the street environment and its associated effect on walking behavior. Ewing and Handy [22] used this framework in the enhancement of walking as a mode of transportation and as a means of recreation, socialization, and health improvement. Recent literature on walkability proves conflict in the identification of walkability and its factors and methods assessing them. Therefore, choosing the walkability framework of Ewing and Handy was justified, as it concentrates on enhancing walkability through respecting the human perception of the urban built environment qualities, in a way attracting people to use walking as a means of transport, entertainment, and recreation. The framework is based on five main urban design qualities enhancing walkability, shown in Fig. 2, and derived from an expert panel in terms of streets physical characteristics and edges: imageability, enclosure, human scale, transparency, and complexity [3].

Ewing and Handy [22] assembled the experience of 10 experts in the field of urban design and planning. They were able to qualitatively define urban design qualities and physical features, through several interviews undertaken to provide qualitative insights into the qualities of streetscape. These qualities are measured by using rated different scenes with respect to them, upon which a manual of draft field survey was presented to describe the urban design qualities as follows:

Imageability can maintain the area distinct and leaving a recognizable image in the visitors' minds. Enclosure is a sensation of an urban space related to its dimensions and the width and Hight of its vertical elements such as trees, walls, and buildings facades. Human scale describes that how urban spaces elements of street furniture and their properties - such as sidewalks and their pavement textures or the like - match the size and proportions of humans. Transparency indicates how the level of perceiving human activities beyond the edges of streets such as walls, trees, textures, and other identifiers can be assigned. Complexity refers to the richness of details found in urban spaces that are related to the components of the physical environment and their numbers and arrangement, such as buildings, landscape, streetscape, signage, and the moving elements in the area [22].

As shown in Fig. 3, the researcher has formulated a conceptual framework based on Ewing's and Handy's framework to be applied to the study area. This framework is based on three main phases concerning the evaluation of the five factors mentioned in Ewing's and Handy's framework elements, imageability, enclosure, human scale, transparency, and complexity. In phase one, a comprehensive survey on the existing streets of the study area, their physical elements, and their related sensations, is undertaken through site visits by using a detailed evaluation list measuring the five factors mentioned above -TABLE 1. Phase two is the stage of analyzing the data gained in phase one to identify the problems found in the study area causing the deficiencies and failure in its walkability system, and the requirements which have a prominent role in solving these problems will be listed afterwards. Finally, phase three concludes the main core design guidelines that will be addressed as the procedures taken as prioritized actions in a reimaging based implementation plan.

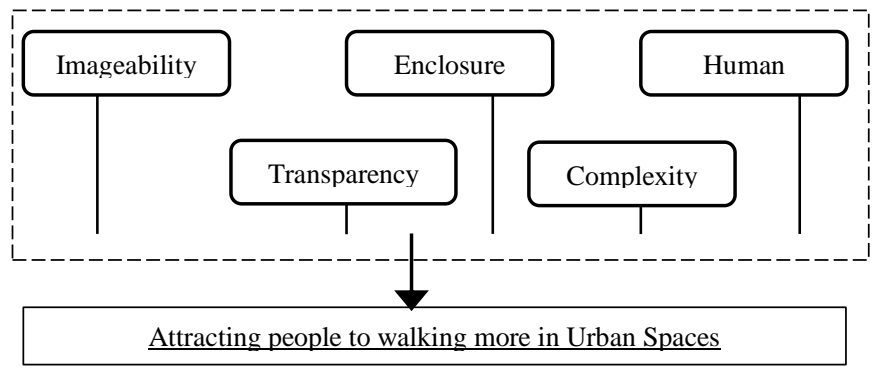

Fig. 2. Factors of urban design qualities proposed by Ewing and Handy. Derived from [22]

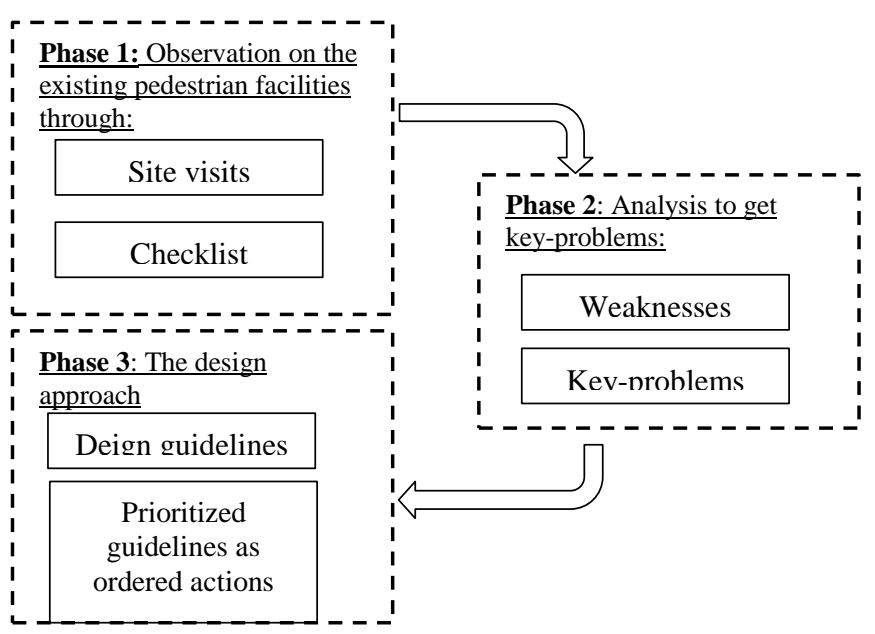

Fig. 3. The main research conceptual framework. The author 
TABLE 1

SAMPLE CHECKLIST OF URBAN DESIGN QUALITIES AND THEIR INDICATORS

\begin{tabular}{|c|c|c|c|c|c|c|}
\hline \multirow{2}{*}{$\begin{array}{l}\text { Urban design } \\
\text { qualities }\end{array}$} & \multirow{2}{*}{ Indicators } & \multicolumn{5}{|c|}{ Verification level } \\
\hline & & $\begin{array}{r}\text { Not } \\
\text { exist }\end{array}$ & Low & Medium & High & $\%$ \\
\hline \multirow{7}{*}{ Imageability } & $\begin{array}{ll}\begin{array}{l}\text { Good } \\
\text { design }\end{array} & \text { urban } \\
\end{array}$ & & & & & \\
\hline & $\begin{array}{l}\text { Landmarks and } \\
\text { uniqueness }\end{array}$ & & & & & \\
\hline & $\begin{array}{l}\text { Arts and sight } \\
\text { attraction }\end{array}$ & & & & & \\
\hline & Paths & & & & & \\
\hline & $\begin{array}{l}\text { Pedestrian } \\
\text { linkages }\end{array}$ & & & & & \\
\hline & $\begin{array}{l}\text { Valuable } \\
\text { buildings }\end{array}$ & & & & & \\
\hline & $\begin{array}{l}\text { Clarity and } \\
\text { visual sequence }\end{array}$ & & & & & \\
\hline \multirow{4}{*}{ Enclosure } & Sense of places & & & & & \\
\hline & $\begin{array}{l}\text { Heights and } \\
\text { widths ratios }\end{array}$ & & & & & \\
\hline & $\begin{array}{l}\text { Feel of shelter } \\
\text { and comfort }\end{array}$ & & & & & \\
\hline & $\begin{array}{l}\text { Sense by } \\
\text { contrast }\end{array}$ & & & & & \\
\hline \multirow{5}{*}{ Human scale } & $\begin{array}{l}\text { Restriction of } \\
\text { vehicle access }\end{array}$ & & & & & \\
\hline & $\begin{array}{l}\text { Quality of } \\
\text { textures }\end{array}$ & & & & & \\
\hline & $\begin{array}{l}\text { Pedestrian } \\
\text { safety }\end{array}$ & & & & & \\
\hline & $\begin{array}{l}\text { Assisting } \\
\text { access facilities }\end{array}$ & & & & & \\
\hline & $\begin{array}{l}\text { Satisfaction } \\
\text { with services }\end{array}$ & & & & & \\
\hline \multirow{5}{*}{ Transparency } & $\begin{array}{l}\text { Destination } \\
\text { accessibility }\end{array}$ & & & & & \\
\hline & $\begin{array}{l}\text { Access to } \\
\text { important zones }\end{array}$ & & & & & \\
\hline & $\begin{array}{l}\text { Walkways } \\
\text { clarity }\end{array}$ & & & & & \\
\hline & $\begin{array}{l}\text { Public access to } \\
\text { amenities }\end{array}$ & & & & & \\
\hline & $\begin{array}{l}\text { Consistency of } \\
\text { landscape } \\
\text { elements }\end{array}$ & & & & & \\
\hline \multirow{5}{*}{ Complexity } & $\begin{array}{l}\text { Connection to } \\
\text { public } \\
\text { transportation }\end{array}$ & & & & & \\
\hline & $\begin{array}{l}\text { High standard } \\
\text { facilities }\end{array}$ & & & & & \\
\hline & $\begin{array}{l}\text { Variety, } \\
\text { richness, and } \\
\text { harmony }\end{array}$ & & & & & \\
\hline & $\begin{array}{l}\text { Side streets and } \\
\text { back alleys }\end{array}$ & & & & & \\
\hline & $\begin{array}{l}\text { Exploiting } \\
\text { underutilized } \\
\text { spaces }\end{array}$ & & & & & \\
\hline
\end{tabular}

Using the checklist of urban design qualities indicators would help the researcher to extract the key problems affecting the urban design qualities of the study area, and because of them the study area may be not an encouraging environment for walking, table1 is used for listing the key problems that are found in the study area and extracted as results of applying the indicators checklist, described in TABLE 2, for performing the field survey. The process of using the indicators of urban design qualities and concluding their related key problems is a continuous closed path operation; the key problems implied from the indicators during the field survey can be used as feedback to emphasize the impact of Ewing's and Handy's factors of urban design qualities by estimating their correlation degree with respect to all factors, shown in Fig. 4. A simple calculation method is used to numerically identify this correlation degree to get the level of importance of the key problems concluded from the field survey, as shown in TABLE 3.

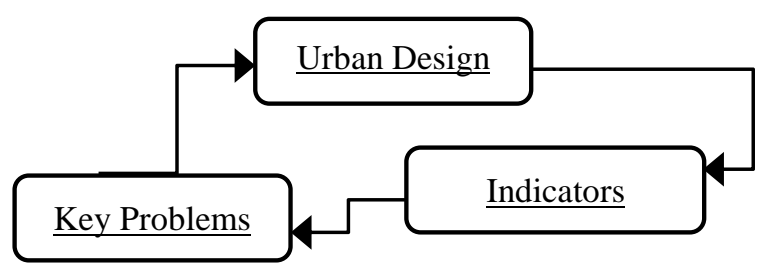

Fig. 4. A closed path process of the research design approach. The author

TABLE 2

The Extracted Key Problems That are Found in The Study ARea

\begin{tabular}{|c|c|c|c|}
\hline $\begin{array}{c}\text { Urban Design } \\
\text { Qualities }\end{array}$ & Indicators & $\begin{array}{c}\text { Verification } \\
\text { Level } \\
\%\end{array}$ & $\begin{array}{c}\text { Extracted Key } \\
\text { Problems }\end{array}$ \\
\hline \multirow{4}{*}{ Imageability } & Indicator 1 & Level for 1 & $\begin{array}{ll}\text { Extracted } & \text { Key } \\
\text { Problem 1 } & \\
\end{array}$ \\
\hline & Indicator 2 & Level for 2 & $\begin{array}{ll}\text { Extracted } & \text { Key } \\
\text { Problem } 2 & \\
\end{array}$ \\
\hline & & & \\
\hline & & & \\
\hline \multicolumn{4}{|l|}{ Enclosure } \\
\hline \multirow{2}{*}{\multicolumn{4}{|c|}{ Human Scale }} \\
\hline & & & \\
\hline \multicolumn{4}{|l|}{ Transparency } \\
\hline \multicolumn{4}{|l|}{ Complexity } \\
\hline & Indicator $\mathrm{n}$ & Level for $n$ & $\begin{array}{l}\text { Extracted } \\
\text { Problem n }\end{array}$ \\
\hline
\end{tabular}


TABLE 3

IDENTIFICATION OF THE LEVEL OF IMPORTANCE OF THE KEY PROBLEMS

\begin{tabular}{|c|c|c|c|c|c|c|c|}
\hline \multirow[b]{2}{*}{$\begin{array}{c}\text { Key } \\
\text { Problems }\end{array}$} & \multicolumn{5}{|c|}{$\begin{array}{l}\text { Correlation to Urban } \\
\text { Design Qualities }\end{array}$} & \multirow[b]{2}{*}{$\underset{/ 5}{\text { Sum. }}$} & \multirow[b]{2}{*}{$\begin{array}{c}\text { Percentage } \\
\%\end{array}$} \\
\hline & 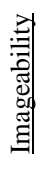 & 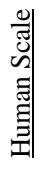 & 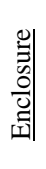 & 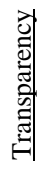 & 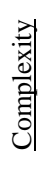 & & \\
\hline \multicolumn{8}{|l|}{$\begin{array}{l}\text { Key } \\
\text { Problem } 1\end{array}$} \\
\hline \multicolumn{8}{|l|}{$\begin{array}{l}\text { Key } \\
\text { Problem } 2 \\
\end{array}$} \\
\hline & & & & & & & \\
\hline & & & & 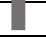 & & & \\
\hline & 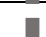 & & & $\pi$ & & & $\pi$ \\
\hline $\begin{array}{l}\text { Key } \\
\text { Problem n }\end{array}$ & & & & 7 & & & \\
\hline
\end{tabular}

\section{CASE Study: ElGomhouria Street, MANSOURA}

Located on the northern part of the city, El Gomhouria street is one of the most important streets in Mansoura; the street connects the city from north to south and includes the majority of its vital districts along its expansion, shown in Pic. 4. The street is remarked to be busy and crowd in most hours of the day because it is frequented by large numbers of people coming from everywhere inside and outside the city, for shopping, receiving their services from governmental authorities existing in the area, and for hiking and relaxation. The role of the study area is dominated by the existence of Mansoura University campus and its famous healthcare and medical research buildings on the southern side, and a lot of high buildings with residential, administrative, and commercial uses blocking the view to the River Nile on the northern side of the study area. The urban fabric of the study area is characterized by its structural density and absence of more spaces in-between buildings, so it is crowded with buildings penetrated by a number of pathways of 6 to 8 meters wide connecting the study area with lowest part located directly on the River Nile shore.

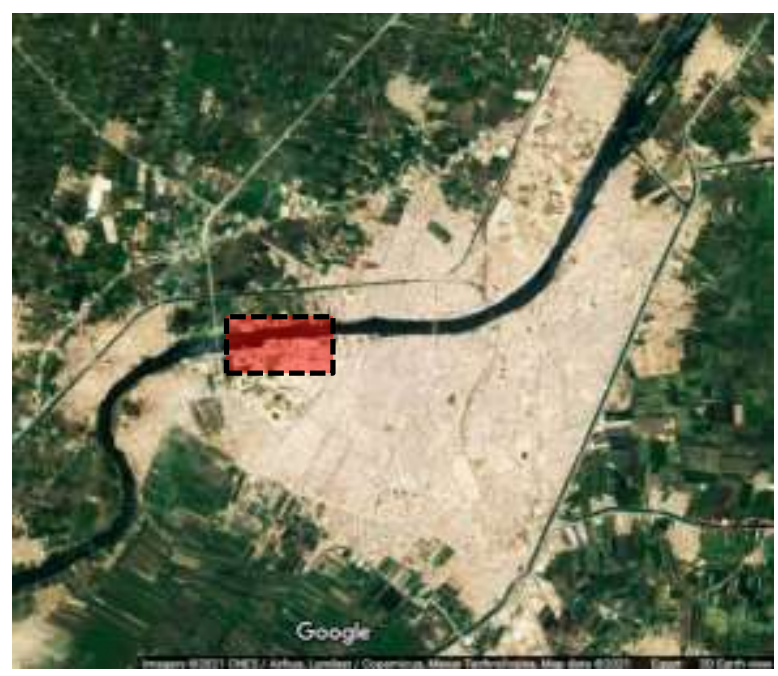

Pic. 5. Location of the study area in the city of Mansoura. [23]

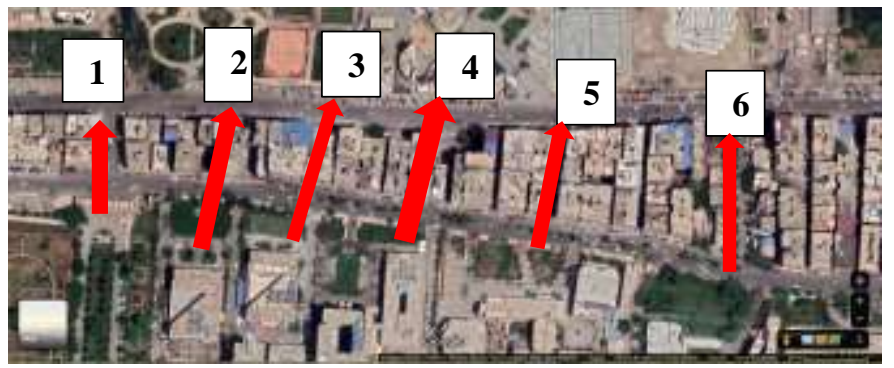

PIC. 6. Locations of observation points in the study area in the city of Mansoura. The author

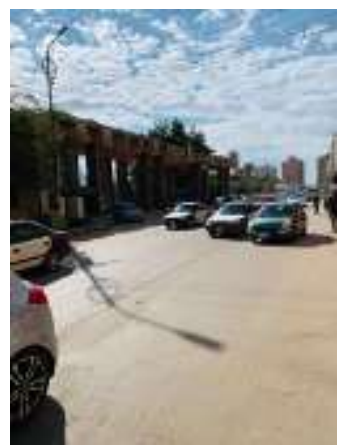

1- Vehicle's domination

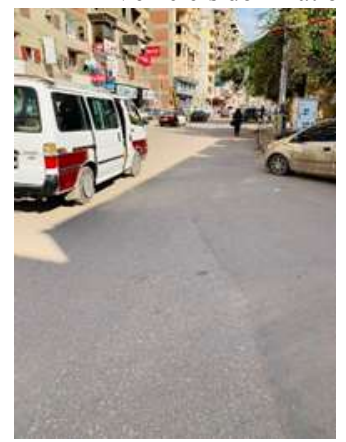

3- Traffic congestion

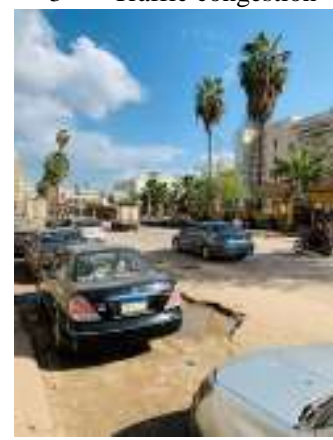

5- Low standard streetscape

Pic. 7. Images from observation points located in the study area.

The author
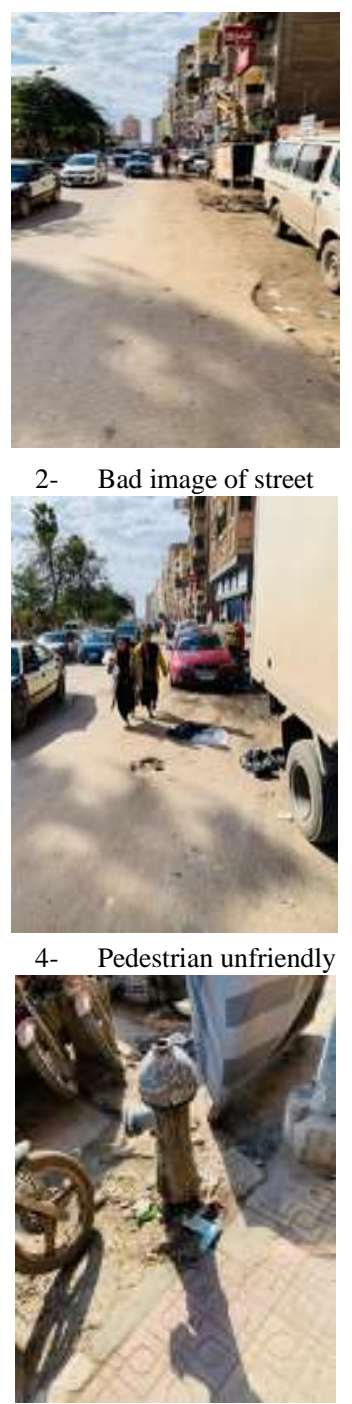

6- $\quad$ Bad sidewalks
Through the field survey and visiting the site in certain observation points, shown in figure 9 and figure 10, the researcher used the evaluation list of urban design qualities described in the previous section and found that the majority of people visited the study area during the peak hours between $10 \mathrm{am}$ to $3 \mathrm{pm}$ in the morning and between $7 \mathrm{pm}$ and $9 \mathrm{pm}$ in the evening. Moreover, the study area was congested in all its zones with all types of vehicles, two wheelers, three wheelers, and pedestrians are all sharing the same road space with 
vehicle type of cars, buses, and trucks. Furthermore, the image of the street and public spaces is distracting, full of dust, scattered, and ambiguous. The identity of the study area is missing because of the whole dominance of vehicles movement on it, the difficulty of pedestrian movement, and the nonexistence of spaces providing safe, comfortable, recreational, and enjoyable walking time in the area. The discontinuity of sidewalks, lack of their maintenance, the low standard streetscape and landscape elements, and the shortage of other pedestrian facilities and ancillary services added more obscurity and mystery to the image of the street and its identity for walking, shown in Pic. 5, Fig. 5, and Fig. 6. All these problems were addressed in the evaluation list and sophistically analyzed to introduce a number of solutions that would act as design guidelines for the target design approach of the research, which is thoroughly discussed below in the next section.

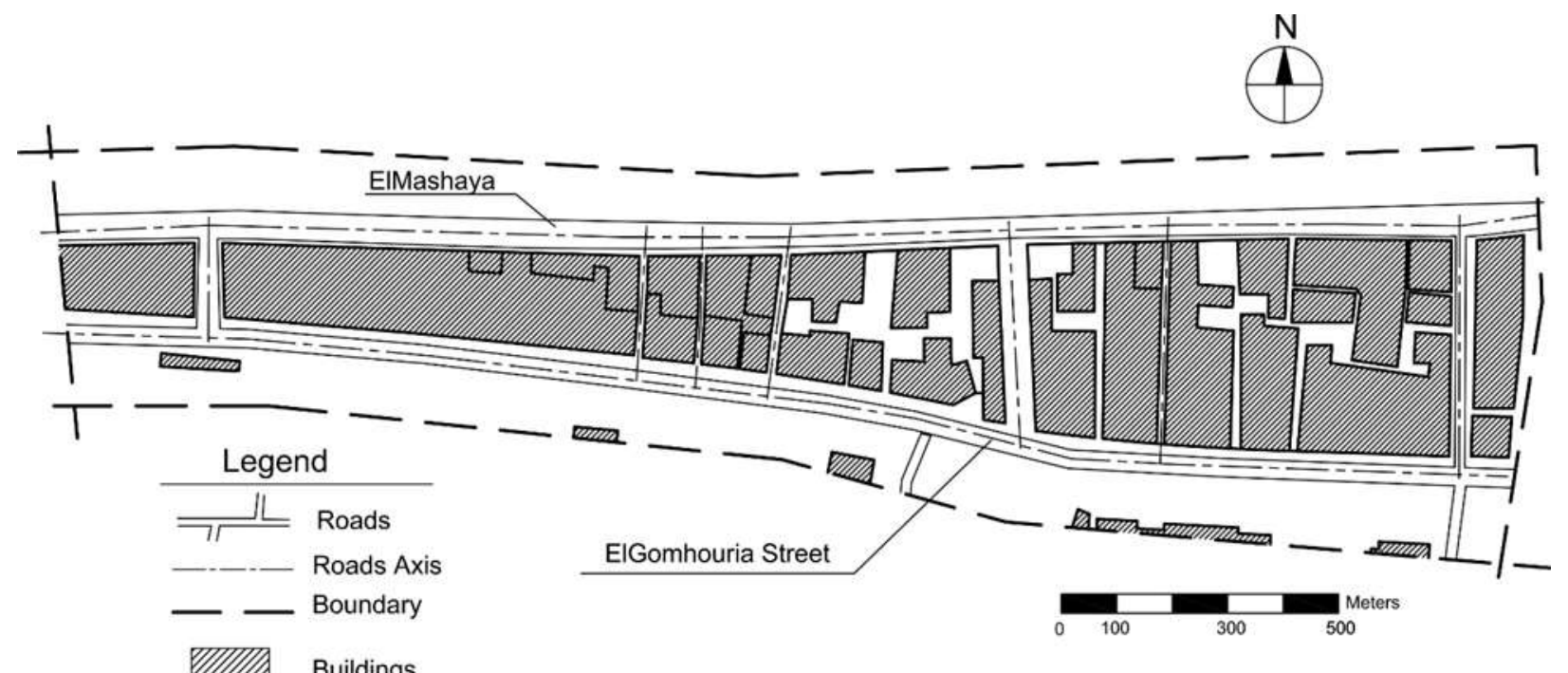

Fig 5. Road density, road center lines and buildings footprints in the study area. Retrieved from [23].

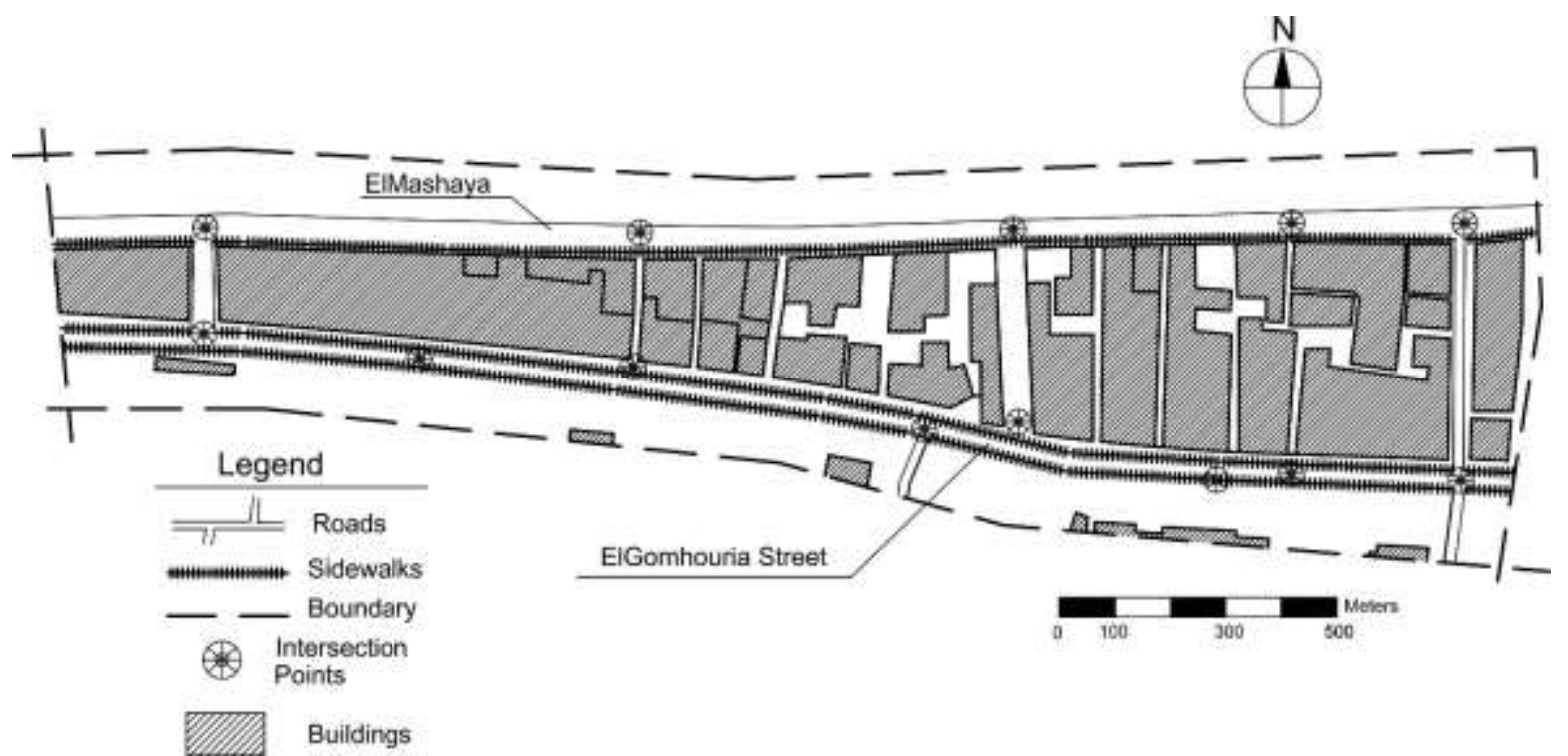

Fig. 6. Sidewalks availability and intersection points in the study area. Retrieved from [23]

\section{RESUlts AND Discussion}

When the researcher conducted the field survey, he monitored the study area from an aesthetic, formative and functional perspective, and filled out the checklist, as shown in TABLE 4, by using its included indicators of the urban design qualities proposed by Erwin and Handy in their framework. According to results shown in the checklist, the study area is largely lacking in aesthetics and visual attractions that usually ensure the imageability factor and strengthen the mental connection between people and the elements of the built environment. The indicators related to good urban design and its elements, quality of sight attraction, paths, pedestrian linkages, and harmony and visual consistency proved that these factors are proved to get not exist verification level. Furthermore, the indicators related to landmarks, landscape 
and other eye-catching elements are proved to get low verification level. All of these have indicated that the imageability factor of the study area needs a comprehensive rehabilitation process, especially for its essential and effective elements.

The indicators related to the enclosure factor concerning the sense of spaces, ratios of buildings and spaces dimensions, feeling of shelter and comfort, and creating senses inside the spaces are proved to get low verification level. The assessment of this factor has demonstrated that the problems related to the enclosure factor needs a rehabilitation plan, but it comes in the second level of priority after the imageability plan. Moreover, human scale indicators of vehicle access domination, walkways quality, accessibility, safety, and service satisfaction, have proved that there is a real problem facing the users of the region in terms of safety, comfort, feasibility of use and satisfaction, because the assessment of these elements does not exceed the low verification level. Therefore, the human scale factor needs a quick and immediate intervention with urgent design guidelines.

The transparency factor is also in real problem as its indicators concerning walking continuity, accessibility to important zones, and comfort and enjoyment of walking proved to get not exist and low verification level, but it comes in the second degree of priority after human scale and needs intervention with the suitable procedures for that. Finally, the complexity factor includes the complementary elements for other factors of urban design qualities, imageability, enclosure, human scale, and transparency, as its indicators are closely correlated with other factors indicators and the way they perform. Therefore, it was logical that the measurements related to complexity indicators are close to the measurements of other indicators of the other factors; the indicators of connection to other means of transportation, standard of facilities maintenance, and care of side streets and back alleys have proved to get not exist level of verification, furthermore, the indicators of the existing streetscape elements and exploiting underutilized spaces have proved to get low level of verification. All in all, according to the results of using the checklist and discussed above, the key problems concerning the urban design qualities of the study area can be extracted as listed below, and as shown in TABLE 5, they can be addressed in comparison to their related indicators:

1. Lack of open spaces.

2. Poor streetscape and landscape elements.

3. Weakness of visual attraction.

4. Lack of maintenance.

5. Separation and lack of clarity.

6. Lack of feeling of shelter and comfort.

7. Difficulty of pedestrian movement.

8. Weakness of the sense of spaces.

9. Weakness of scale and proportion.

10. Traffic congestion and vehicles dominance.

11. Lack of pedestrian facilities.

12. Sidewalks discontinuity and difficulty to use.

13. Missing safety and pedestrian friendly.

14. Lack of services and amenities.
TABLE 4

The ChECKLIST With The Results ObTAINED From Site Visits

\begin{tabular}{|c|c|c|c|c|c|c|}
\hline \multirow{2}{*}{$\begin{array}{l}\text { Urban } \\
\text { design } \\
\text { qualities }\end{array}$} & \multirow{2}{*}{ Indicators } & \multicolumn{5}{|c|}{ Verification level } \\
\hline & & $\begin{array}{r}\text { Not } \\
\text { exist }\end{array}$ & Low & Medium & High & $\%$ \\
\hline \multirow{7}{*}{ Imageability } & $\begin{array}{l}\text { Good urban } \\
\text { design }\end{array}$ & $\sqrt{ }$ & & & & 0 \\
\hline & $\begin{array}{l}\text { Landmarks } \\
\text { and } \\
\text { uniqueness }\end{array}$ & & $\sqrt{ }$ & & & 30 \\
\hline & $\begin{array}{l}\text { Arts and } \\
\text { sight } \\
\text { attraction }\end{array}$ & $\sqrt{ }$ & & & & 0 \\
\hline & Paths & $\sqrt{ }$ & & & & 0 \\
\hline & $\begin{array}{l}\text { Pedestrian } \\
\text { linkages }\end{array}$ & $\sqrt{ }$ & & & & 0 \\
\hline & $\begin{array}{l}\text { Valuable } \\
\text { buildings }\end{array}$ & & $\sqrt{ }$ & & & 35 \\
\hline & $\begin{array}{l}\text { Clarity and } \\
\text { visual } \\
\text { sequence }\end{array}$ & $\sqrt{ }$ & & & & 0 \\
\hline \multirow{4}{*}{ Enclosure } & $\begin{array}{l}\text { Sense of } \\
\text { places }\end{array}$ & & $\sqrt{ }$ & & & 35 \\
\hline & $\begin{array}{l}\text { Heights and } \\
\text { widths ratios }\end{array}$ & & $\sqrt{ }$ & & & 30 \\
\hline & $\begin{array}{l}\text { Feel of } \\
\text { shelter and } \\
\text { comfort }\end{array}$ & & $\sqrt{ }$ & & & 30 \\
\hline & $\begin{array}{l}\text { Sense by } \\
\text { contrast }\end{array}$ & & $\sqrt{ }$ & & & 25 \\
\hline \multirow{5}{*}{ Human scale } & $\begin{array}{l}\text { Restriction of } \\
\text { vehicle } \\
\text { access }\end{array}$ & $\sqrt{ }$ & & & & 0 \\
\hline & $\begin{array}{l}\text { Quality of } \\
\text { textures }\end{array}$ & & $\sqrt{ }$ & & & 25 \\
\hline & $\begin{array}{l}\text { Pedestrian } \\
\text { safety }\end{array}$ & & $\sqrt{ }$ & & & 25 \\
\hline & $\begin{array}{l}\text { Assisting } \\
\text { access } \\
\text { facilities }\end{array}$ & $\sqrt{ }$ & & & & 0 \\
\hline & $\begin{array}{l}\text { Satisfaction } \\
\text { with services }\end{array}$ & & & $\sqrt{ }$ & & 45 \\
\hline \multirow{5}{*}{ Transparency } & $\begin{array}{l}\text { Destination } \\
\text { accessibility }\end{array}$ & $\sqrt{ }$ & & & & 0 \\
\hline & $\begin{array}{l}\text { Access to } \\
\text { important } \\
\text { zones }\end{array}$ & & $\sqrt{ }$ & & & 25 \\
\hline & $\begin{array}{l}\text { Walkways } \\
\text { clarity }\end{array}$ & & $\sqrt{ }$ & & & 30 \\
\hline & $\begin{array}{l}\text { Public access } \\
\text { to amenities }\end{array}$ & & $\sqrt{ }$ & & & 25 \\
\hline & $\begin{array}{l}\text { Consistency } \\
\text { of landscape } \\
\text { elements }\end{array}$ & $\sqrt{ }$ & & & & 0 \\
\hline \multirow{5}{*}{ Complexity } & $\begin{array}{l}\text { Connection } \\
\text { to public } \\
\text { transportation }\end{array}$ & $\sqrt{ }$ & & & & 0 \\
\hline & $\begin{array}{l}\text { High } \\
\text { standard } \\
\text { facilities }\end{array}$ & $\sqrt{ }$ & & & & 0 \\
\hline & $\begin{array}{l}\text { Variety, } \\
\text { richness, and } \\
\text { harmony }\end{array}$ & & $\sqrt{ }$ & & & 25 \\
\hline & $\begin{array}{lr}\begin{array}{l}\text { Side } \\
\text { and }\end{array} & \text { streets } \\
\text { alleys } & \text { back } \\
\end{array}$ & $\sqrt{ }$ & & & & 0 \\
\hline & $\begin{array}{l}\text { Exploiting } \\
\text { underutilized } \\
\text { spaces }\end{array}$ & & $\sqrt{ }$ & & & 40 \\
\hline
\end{tabular}


TABLE 5

The Key Problems Concerning The URBan Design Qualities of The STUDY AREA

\begin{tabular}{|c|c|c|c|}
\hline $\begin{array}{c}\text { Urban Design } \\
\text { Qualities }\end{array}$ & Indicators & $\begin{array}{c}\text { Verification } \\
\text { Level } \\
\%\end{array}$ & $\begin{array}{l}\text { Extracted Key } \\
\text { Problems }\end{array}$ \\
\hline \multirow{7}{*}{ Imageability } & $\begin{array}{l}\text { Good urban } \\
\text { design }\end{array}$ & 0 & $\begin{array}{l}\begin{array}{l}\text { Lack of } \\
\text { spaces }\end{array} \\
\end{array}$ \\
\hline & $\begin{array}{l}\text { Landmarks } \\
\text { and } \\
\text { uniqueness }\end{array}$ & 30 & $\begin{array}{l}\text { Weakness of } \\
\text { visual attraction }\end{array}$ \\
\hline & $\begin{array}{l}\text { Arts and sight } \\
\text { attraction }\end{array}$ & 0 & $\begin{array}{l}\text { Weakness of } \\
\text { visual attraction }\end{array}$ \\
\hline & Paths & 0 & $\begin{array}{ll}\text { Lack } & \text { of } \\
\text { maintenance } & \end{array}$ \\
\hline & $\begin{array}{l}\text { Pedestrian } \\
\text { linkages }\end{array}$ & 0 & $\begin{array}{l}\text { Separation and } \\
\text { lack of clarity }\end{array}$ \\
\hline & $\begin{array}{l}\text { Valuable } \\
\text { buildings }\end{array}$ & 35 & $\begin{array}{l}\text { Weakness of } \\
\text { visual attraction }\end{array}$ \\
\hline & $\begin{array}{l}\text { Clarity and } \\
\text { visual } \\
\text { sequence }\end{array}$ & 0 & $\begin{array}{l}\text { Separation and } \\
\text { lack of clarity }\end{array}$ \\
\hline \multirow{4}{*}{ Enclosure } & $\begin{array}{ll}\begin{array}{l}\text { Sense } \\
\text { places }\end{array} & \text { of } \\
\end{array}$ & 35 & $\begin{array}{l}\text { Weakness of the } \\
\text { sense }\end{array}$ \\
\hline & $\begin{array}{l}\text { Heights and } \\
\text { widths ratios }\end{array}$ & 30 & $\begin{array}{l}\text { Weakness of scale } \\
\text { and proportion }\end{array}$ \\
\hline & $\begin{array}{lr}\text { Feel } & \text { of } \\
\text { shelter } & \text { and } \\
\text { comfort } & \end{array}$ & 30 & $\begin{array}{l}\text { Lack of feeling of } \\
\text { shelter and } \\
\text { comfort }\end{array}$ \\
\hline & $\begin{array}{ll}\begin{array}{l}\text { Sense } \\
\text { contrast }\end{array} & \text { by }\end{array}$ & 25 & $\begin{array}{l}\text { Weakness of the } \\
\text { sense of spaces }\end{array}$ \\
\hline \multirow{5}{*}{ Human Scale } & $\begin{array}{l}\text { Restriction of } \\
\text { vehicle } \\
\text { access }\end{array}$ & 0 & $\begin{array}{l}\text { Traffic congestion } \\
\text { and vehicles } \\
\text { dominance }\end{array}$ \\
\hline & $\begin{array}{l}\text { Quality of } \\
\text { textures }\end{array}$ & 25 & $\begin{array}{l}\text { Lack of pedestrian } \\
\text { facilities }\end{array}$ \\
\hline & $\begin{array}{l}\text { Pedestrian } \\
\text { safety }\end{array}$ & 25 & $\begin{array}{l}\text { Missing safety and } \\
\text { pedestrian friendly }\end{array}$ \\
\hline & $\begin{array}{l}\text { Assisting } \\
\text { access } \\
\text { facilities }\end{array}$ & 0 & $\begin{array}{l}\text { Lack of pedestrian } \\
\text { facilities }\end{array}$ \\
\hline & $\begin{array}{l}\text { Satisfaction } \\
\text { with services }\end{array}$ & 45 & $\begin{array}{lr}\text { Lack of } & \text { services } \\
\text { and } & \text { leisure } \\
\text { amenities } & \\
\end{array}$ \\
\hline \multirow{5}{*}{ Transparency } & $\begin{array}{l}\text { Destination } \\
\text { accessibility }\end{array}$ & 0 & $\begin{array}{l}\text { Lack of pedestrian } \\
\text { facilities }\end{array}$ \\
\hline & $\begin{array}{l}\text { Access to } \\
\text { important } \\
\text { zones }\end{array}$ & 25 & $\begin{array}{l}\text { Difficulty of } \\
\text { pedestrian } \\
\text { movement }\end{array}$ \\
\hline & $\begin{array}{l}\text { Walkways } \\
\text { clarity }\end{array}$ & 30 & $\begin{array}{l}\text { Sidewalks } \\
\text { discontinuity and } \\
\text { difficulty to use }\end{array}$ \\
\hline & $\begin{array}{l}\text { Public access } \\
\text { to amenities }\end{array}$ & 25 & $\begin{array}{l}\text { Lack of services } \\
\text { and amenities }\end{array}$ \\
\hline & $\begin{array}{l}\text { Consistency } \\
\text { of landscape } \\
\text { elements }\end{array}$ & 0 & $\begin{array}{l}\text { Weakness of scale } \\
\text { and proportion }\end{array}$ \\
\hline \multirow{3}{*}{ Complexity } & $\begin{array}{l}\text { Connection to } \\
\text { public } \\
\text { transportation }\end{array}$ & 0 & $\begin{array}{l}\text { Sidewalks } \\
\text { discontinuity and } \\
\text { difficulty to use }\end{array}$ \\
\hline & $\begin{array}{l}\text { High standard } \\
\text { facilities }\end{array}$ & 0 & $\begin{array}{ll}\text { Lack } & \text { of } \\
\text { maintenance } & \end{array}$ \\
\hline & Variety, & 25 & Poor streetscape \\
\hline
\end{tabular}

\begin{tabular}{||l||l||l} 
& $\begin{array}{l}\text { richness, and } \\
\text { harmony }\end{array}$ & $\begin{array}{l}\text { and landscape } \\
\text { elements }\end{array}$ \\
\hline $\begin{array}{l}\text { Side streets } \\
\text { and back } \\
\text { alleys }\end{array}$ & 0 & $\begin{array}{l}\text { Missing safety and } \\
\text { pedestrian friendly } \\
\text { factors }\end{array}$ \\
\hline $\begin{array}{l}\text { Exploiting } \\
\text { underutilized } \\
\text { spaces }\end{array}$ & 40 & $\begin{array}{l}\text { Lack of pedestrian } \\
\text { facilities }\end{array}$ \\
\hline
\end{tabular}

The extracted key-problems found from the filed survey by using the urban design qualities checklist are processed in a feedback process to analyze their importance in accordance with their percentage of belonging to the overall factors of urban design qualities, imageability, enclosure, human scale, transparency, and complexity. This feedback process is performed by using a matrix shown in TABLE 6, and the concept of this matrix is based on listing the overall keyproblems vertically and the overall urban design qualities horizontally to check the possibility of a key-problem to be related to one or more factors of urban design qualities, and then calculating the percentage of this relationship, shown in TABLE 6 and Fig. 7. Based on these percentages, the priorities can be arranged, and the key-problems can be translated to several core design guidelines formulating a design approach and representing its orderly included actions and their delivery times, shown in TABLE 7, and recommended to be considered in urban upgrade processes concerning reimaging the streets and enhancing the open spaces inside the study area. By adopting and implementing this design approach, the walkability inside the study area is expected to be enhanced and get improved significantly and in the earliest time frames.

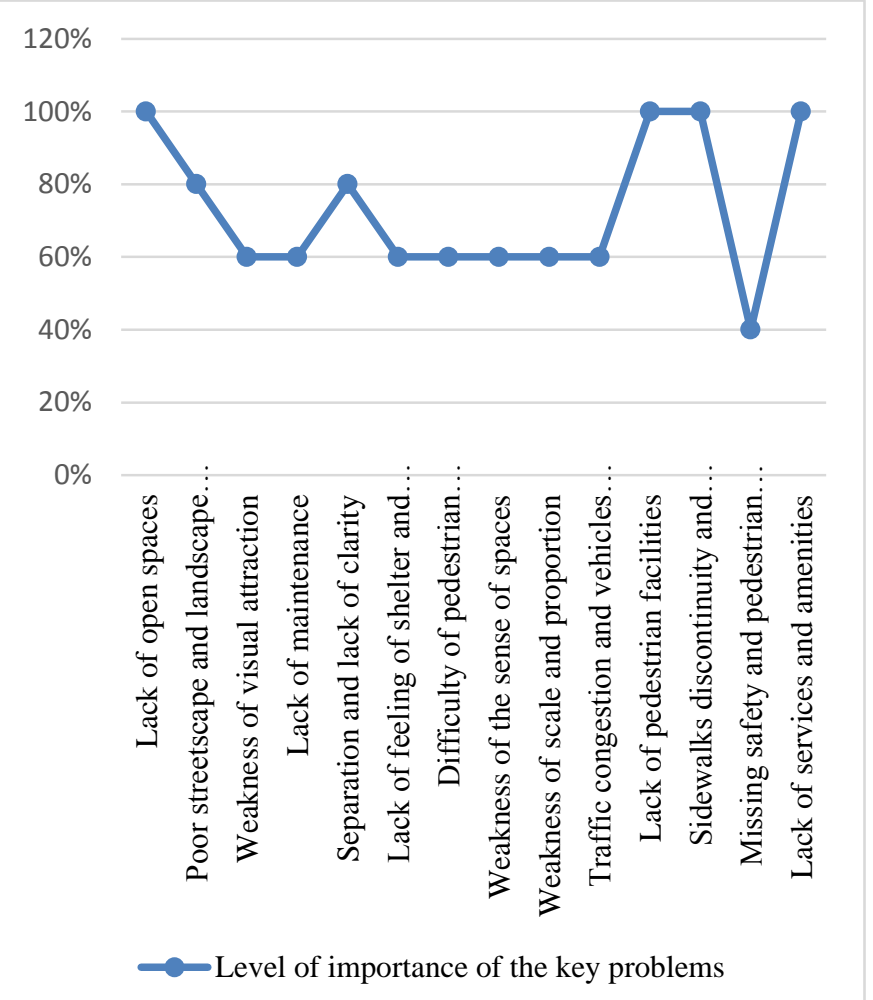

Fig. 7. Key problems Found in the Study area and their levels of importance according to the factors of urban design qualities. The author 
TABLE 6

THE RESUlts of CALCULATING LEVElS OF IMPORTANCE OF THE KeY PROBLEMS

\begin{tabular}{|c|c|c|c|c|c|c|c|}
\hline \multirow[b]{2}{*}{$\begin{array}{c}\text { Key } \\
\text { Problems }\end{array}$} & & $\begin{array}{l}\text { rrela } \\
\text { Desig }\end{array}$ & $\begin{array}{l}\text { tion } \\
\text { n } Q u\end{array}$ & $\begin{array}{l}\text { PRO } \\
\text { Urt } \\
\text { litie }\end{array}$ & BLEM & & \multirow[b]{2}{*}{$\begin{array}{c}\text { Percentage } \\
\%\end{array}$} \\
\hline & 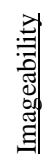 & 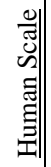 & 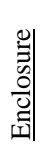 & 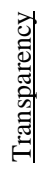 & 就 & $\underset{/ 5}{\operatorname{Sum}}$ & \\
\hline $\begin{array}{l}\text { Lack of open } \\
\text { spaces. }\end{array}$ & $\sqrt{ }$ & $\sqrt{ }$ & $\sqrt{ }$ & $\sqrt{ }$ & $\sqrt{ }$ & $5 / 5$ & $100 \%$ \\
\hline $\begin{array}{l}\text { Poor } \\
\text { streetscape } \\
\text { and } \\
\text { landscape } \\
\text { elements }\end{array}$ & $\sqrt{ }$ & $\sqrt{ }$ & $\sqrt{ }$ & & $\sqrt{ }$ & $4 / 5$ & $80 \%$ \\
\hline $\begin{array}{l}\text { Weakness of } \\
\text { visual } \\
\text { attraction }\end{array}$ & $\sqrt{ }$ & & $\sqrt{ }$ & $\sqrt{ }$ & & $3 / 5$ & $60 \%$ \\
\hline $\begin{array}{l}\text { Lack of } \\
\text { maintenance }\end{array}$ & $\sqrt{ }$ & & $\sqrt{ }$ & & $\sqrt{ }$ & $3 / 5$ & $60 \%$ \\
\hline $\begin{array}{l}\text { Separation } \\
\text { and lack of } \\
\text { clarity }\end{array}$ & $\sqrt{ }$ & $\sqrt{ }$ & & $\sqrt{ }$ & $\sqrt{ }$ & $4 / 5$ & $80 \%$ \\
\hline $\begin{array}{lr}\text { Lack } & \text { of } \\
\text { feeling } & \text { of } \\
\text { shelter and } \\
\text { comfort }\end{array}$ & $\sqrt{ }$ & $\sqrt{ }$ & $\sqrt{ }$ & & & $3 / 5$ & $60 \%$ \\
\hline $\begin{array}{l}\text { Difficulty of } \\
\text { pedestrian } \\
\text { movement }\end{array}$ & $\sqrt{ }$ & & $\sqrt{ }$ & $\sqrt{ }$ & & $3 / 5$ & $60 \%$ \\
\hline $\begin{array}{l}\text { Weakness of } \\
\text { the sense of } \\
\text { spaces }\end{array}$ & & $\sqrt{ }$ & $\sqrt{ }$ & $\sqrt{ }$ & & $3 / 5$ & $60 \%$ \\
\hline $\begin{array}{l}\text { Weakness of } \\
\text { scale and } \\
\text { proportion }\end{array}$ & $\sqrt{ }$ & $\sqrt{ }$ & $\sqrt{ }$ & & & $3 / 5$ & $60 \%$ \\
\hline $\begin{array}{l}\text { Traffic } \\
\text { congestion } \\
\text { and vehicles } \\
\text { dominance }\end{array}$ & $\sqrt{ }$ & $\sqrt{ }$ & $\sqrt{ }$ & & & $3 / 5$ & $60 \%$ \\
\hline $\begin{array}{l}\text { Lack of } \\
\text { pedestrian } \\
\text { facilities }\end{array}$ & $\sqrt{ }$ & $\sqrt{ }$ & $\sqrt{ }$ & $\sqrt{ }$ & $\sqrt{ }$ & $5 / 5$ & $100 \%$ \\
\hline $\begin{array}{l}\text { Sidewalks } \\
\text { discontinuity } \\
\text { and difficulty } \\
\text { to use }\end{array}$ & $\sqrt{ }$ & $\sqrt{ }$ & $\sqrt{ }$ & $\sqrt{ }$ & $\sqrt{ }$ & $5 / 5$ & $100 \%$ \\
\hline $\begin{array}{l}\text { Missing } \\
\text { safety and } \\
\text { pedestrian } \\
\text { friendly }\end{array}$ & & $\sqrt{ }$ & $\sqrt{ }$ & & & $2 / 5$ & $40 \%$ \\
\hline $\begin{array}{l}\text { Lack of } \\
\text { services and } \\
\text { amenities }\end{array}$ & $\sqrt{ }$ & $\sqrt{ }$ & $\sqrt{ }$ & $\sqrt{ }$ & $\sqrt{ }$ & $5 / 5$ & $100 \%$ \\
\hline
\end{tabular}

TABLE 7

THE DESIGN APPROACH FOR WALKABILITY ENHANCEMENT

\begin{tabular}{|c|c|c|c|c|}
\hline \multirow{2}{*}{ Objectives } & \multirow{2}{*}{$\begin{array}{c}\text { Design } \\
\text { guidelines/Actions }\end{array}$} & \multicolumn{3}{|c|}{ Delivery timeframe } \\
\hline & & $\begin{array}{l}2021 / \\
2022 \\
\end{array}$ & $\begin{array}{l}2022 / \\
2023\end{array}$ & Ongoing \\
\hline \multirow{7}{*}{ Imageability } & $\begin{array}{l}\text { Adding more open spaces } \\
\text { and recreational facilities } \\
\text { designed for pedestrians }\end{array}$ & $\sqrt{ }$ & $\sqrt{ }$ & - \\
\hline & $\begin{array}{l}\text { Taking care of landmarks } \\
\text { installation and unique } \\
\text { landscape elements }\end{array}$ & $\sqrt{ }$ & $\sqrt{ }$ & $\sqrt{ }$ \\
\hline & $\begin{array}{l}\text { Adding more powerful } \\
\text { art works and sight } \\
\text { attraction elements }\end{array}$ & $\sqrt{ }$ & $\sqrt{ }$ & $\sqrt{ }$ \\
\hline & $\begin{array}{l}\text { Treatment of walkways } \\
\text { to become direct routes } \\
\text { and well-maintained } \\
\text { paths }\end{array}$ & $\sqrt{ }$ & - & - \\
\hline & $\begin{array}{l}\text { Linking } \\
\text { facilities to } \\
\text { transport }\end{array}$ & $\sqrt{ }$ & - & - \\
\hline & $\begin{array}{l}\text { Adding memorable and } \\
\text { eye-catching buildings, } \\
\text { and distinctive places }\end{array}$ & $\sqrt{ }$ & $\sqrt{ }$ & $\sqrt{ }$ \\
\hline & $\begin{array}{l}\text { Ensuring clarity of visual } \\
\text { links between all existing } \\
\text { elements of urban built } \\
\text { environment. }\end{array}$ & $\sqrt{ }$ & $\sqrt{ }$ & $\sqrt{ }$ \\
\hline \multirow{4}{*}{ Enclosure } & $\begin{array}{l}\text { Improving senses of } \\
\text { spaces with buildings and } \\
\text { landscape elements }\end{array}$ & $\sqrt{ }$ & - & - \\
\hline & $\begin{array}{l}\text { Seeking visual and } \\
\text { physical solutions to fix } \\
\text { the effect of the existing } \\
\text { building height and street } \\
\text { width ratios to give a } \\
\text { strong feeling of } \\
\text { enclosure }\end{array}$ & $\sqrt{ }$ & - & - \\
\hline & $\begin{array}{l}\text { Creating distinctive } \\
\text { feeling of shelter and } \\
\text { comfort }\end{array}$ & $\sqrt{ }$ & $\sqrt{ }$ & - \\
\hline & $\begin{array}{l}\text { Creating sense by } \\
\text { contrast, variety, and } \\
\text { distinctiveness between } \\
\text { all elements }\end{array}$ & $\sqrt{ }$ & $\sqrt{ }$ & $\sqrt{ }$ \\
\hline \multirow{5}{*}{ Human Scale } & $\begin{array}{l}\text { Totally preventing } \\
\text { vehicle access and } \\
\text { movement in much of the } \\
\text { core of the area }\end{array}$ & $\sqrt{ }$ & - & - \\
\hline & $\begin{array}{l}\text { Improving quality } \text { of } \\
\text { walkways textures and } \\
\text { materials }\end{array}$ & $\sqrt{ }$ & - & - \\
\hline & $\begin{array}{l}\text { Achieve complete safety } \\
\text { for pedestrian movement }\end{array}$ & $\sqrt{ }$ & - & - \\
\hline & $\begin{array}{l}\text { Adding the possible } \\
\text { facilities that are assisting } \\
\text { access for all people } \\
\text { categories }\end{array}$ & $\sqrt{ }$ & - & - \\
\hline & $\begin{array}{l}\text { To get complete } \\
\text { satisfaction with all } \\
\text { services and recreational } \\
\text { facilities }\end{array}$ & $\sqrt{ }$ & $\sqrt{ }$ & - \\
\hline \multirow{4}{*}{ Transparency } & $\begin{array}{l}\text { Enhancing pedestrian } \\
\text { linkages and destination } \\
\text { accessibility }\end{array}$ & $\sqrt{ }$ & $\sqrt{ }$ & - \\
\hline & $\begin{array}{l}\text { Achieving convenient } \\
\text { access to important zones }\end{array}$ & $\sqrt{ }$ & $\sqrt{ }$ & - \\
\hline & $\begin{array}{l}\text { Ensuring clarity } \\
\text { pedestrian walkways }\end{array}$ & $\sqrt{ }$ & & - \\
\hline & $\begin{array}{l}\text { Developing the existing } \\
\text { pedestrian facilities and } \\
\text { amenities to public } \\
\text { access and use for free }\end{array}$ & $\sqrt{ }$ & $\sqrt{ }$ & $\sqrt{ }$ \\
\hline
\end{tabular}




\begin{tabular}{|c|c|c|c|c|}
\hline & \begin{tabular}{lrr} 
Achieving & \multicolumn{2}{r}{ consistency } \\
betwpeen & \multicolumn{2}{r}{ vertical } \\
elements & and & the \\
dimensions & of & urban \\
spaces & & \\
\end{tabular} & $\sqrt{ }$ & $\sqrt{ }$ & $\sqrt{ }$ \\
\hline \multirow{5}{*}{ Complexity } & $\begin{array}{l}\text { Remaking pedestrian } \\
\text { facilities to be well } \\
\text { connected to other means } \\
\text { of transportation }\end{array}$ & $\sqrt{ }$ & $\sqrt{ }$ & - \\
\hline & $\begin{array}{l}\text { Regular maintenance for } \\
\text { all facilities to keep them } \\
\text { in a good standard }\end{array}$ & $\sqrt{ }$ & $\sqrt{ }$ & $\sqrt{ }$ \\
\hline & $\begin{array}{l}\text { Adopting designs giving } \\
\text { variety, richness, and } \\
\text { harmony for streetscape } \\
\text { elements }\end{array}$ & $\sqrt{ }$ & $\sqrt{ }$ & $\sqrt{ }$ \\
\hline & $\begin{array}{l}\text { Taking care of side } \\
\text { streets and back alleys of } \\
\text { the study area }\end{array}$ & $\sqrt{ }$ & $\sqrt{ }$ & - \\
\hline & $\begin{array}{l}\text { Exploiting underutilized } \\
\text { spaces as green, play, and } \\
\text { seating areas for } \\
\text { pedestrians }\end{array}$ & $\sqrt{ }$ & $\sqrt{ }$ & - \\
\hline
\end{tabular}

\section{CONCLUSION}

In conclusion, areas with high residential and intersection density, variety of land uses, and closeness to important destinations have higher levels of potential walkability. In this context, the Egyptian cities are full of areas with that mean, and therefore they have a good chance to be included in the world's most livable cities provided that walkability is supported to be the favorite means of transportation to their citizens. However, earlier literature proved that there was no indication of a certain factor having a major influence on walkability in a specific area. Instead, any indicators related to the visual and functional characteristics of streets and open spaces can be justified, because it is remarked in literature that downtowns scored the highest levels of walkability according to the aesthetic, visual and functional indicators of their streets and open spaces. The research intended to shed the light on El Gomhouria Street, Mansoura as a part of an Egyptian city having many challenges and problems facing pedestrian facilities, such as vehicles domination and lacking safety and effectiveness of walkways connecting major destinations. Therefore, the research provided a design approach based on using urban design qualities as indicators for reimaging redeveloping the urban built environment for walkability.

The design approach proposed by the research adopted the framework of Erwin and Handy which was aiming at enhancing walkability by enhancing human perception of the urban built environment qualities and encouraging people to use walking as a basic means of transport, entertainment, and recreation. The indicators checklist used in the research's design approach could uncover the potential problems existing in the study area and helped the researcher to introduce the suitable design guidelines needed for enhancing walkability opportunities in the study area. The effort made in this research can introduce a better solution to upgrade the urban built environment to improve the cultural and behavioral characteristics of Egyptian citizens, for perceiving their surrounding environments to walk more than ride. The research design approach could give the proof of that cities can encourage pedestrian movement by shifting the focus from cars to people and placing walking back into the core of urban spaces. Furthermore, if walking is needed in Mansoura instead of riding cars, the five factors of urban design qualities, imageability, enclosure, human scale, transparency, and complexity, are critical to a good design approach for a better walking environment.

\section{REFERENCES}

[1] A. El-zemrany and R. Kandil, "Quality of Life in Egypt: Walkability Assessment in El-MansheyaSquare, Alexandria, Egypt," Wit Transactions on The Built Environment, vol. 188, pp. 23 - 34, 2019.

[2] P. de-Cambra, "Pedestrian Accessibility and Attractiveness Indicators for Walkability Assessment," Tecnico Lisboa, 2012.

[3] A. Reagan, "Measuring Walkability in Gainesville's Urban Areas: A Case Study of Millhopper and Downtown," Master, Urban and Regional Planning, University of Florida, 2018.

[4] D. Omar, K. Omar, S. Othman, and Z. Yusoff, "Walkability Design for Urban Public Housing Park," in 7th Asian Conference on EnvironmentBehaviour Studies, 2016, p. 311.

[5] S. Marino. (2017, 19/1/2021). A Walkable City is a Better City. Available: https://www.landdesign.com/a-walkable-city-is-a-better-city/

[6] F. Foti, "A Behavioral Framework for Measuring Walkability and its Impact on Home Values and Residential Location Choices," Doctor of Philosophy, City and Regional Planning, University of California, Berkeley, 2014.

[7] A. Forsyth, "What is a Walkable Place? The Walkability Debate in Urban Design," Urban Design International 20, vol. 20, pp. 274-292, 2015.

[8] V. Crooks, M. Winters, and N. Schuurman, "Walkability and connectivity : unpacking measures of the built environment," 2017.

[9] J. Frilund. (2017, 20/2/2021). Walkability - Set the city free. Available: https://making-cities-safer.com/walkability-set-city-free/

[10] M. Knapskog, H. Hagen, A. Tennoy, and M. Rynning, "Exploring ways of measuring walkability " Transportation Research Procedia, vol. 41, pp. 264-282, 2019.

[11] J. Irvin. (2021, 30/1/2021). Crearting Walking Cities. Available: http://www.activecornwall.org/files/living_streets_creating_walking_cities.pdf

[12] World-Health-Organization. (2020, 27/1/2021). Coronavirus disease (COVID-19) advice for the public. Available: https://www.who.int/emergencies/diseases/novel-coronavirus2019/advice-for-public

[13] L. LiuID, H. Miller, and J. Scheff, "The Impacts of COVID-19 Pandemic on Public Transit Demand in the United States," Plos One, vol. 15, 2020.

[14] L. Walden. (2020, 28/ 1/ 2021). 6 Expert Tips on How to Cope with the Anxiety of Life after lockdown. Available: https://www.countryliving.com/uk/wellbeing/a32455608/anxious-lifeafter-lockdown/

[15] C.-f.-D.-C.-a.-P. CDC. (2020, 28/1/2021). Protect Yourself When Using Transportation: Public transit, rideshares and taxis, micro-mobility devices, and personal vehicles. Available: https://www.cdc.gov/coronavirus/2019-ncov/daily-life-coping/usingtransportation.html

[16] M. Refaat and N. Kafafy, "Approaches and Lessons for enhancing walkability in cities: a Landscape Conceptual Solution for Talaat Harb Street, Cairo," International Journal of Education and Research, vol. 2, 2014.

[17] T. Sharara. (2021, 30/1/2021). Manoura Photography Available: https://www.pinterest.com/pin/789607747139310911/

[18] R. E. Messeidy, "Towards Better Cities: Improving Walkability in Terms of Seven Principles.," Journal of Urban Research, vol. 33, pp. 154-171, 2019.

[19] E. Cerin, B. Saelens, H. Sallis, and L. Frank, "Neighborhood Environment Walkability Scale: Validity and Development of a Short Form," The International Physical Activity and the Environment Network (IPEN), vol. 38, pp. 1682-1691, 2006. 
[20] R. Lambert. (2019, 30/1/2021). How to create walking friendly cities. Available: http://naturalwalkingcities.com/how-to-make-cities-walkingfriendly/

[21] I. Bleci'c, T. Congiu, G. Fancello, and a. G. A. Trunfio, "Planning and Design Support Tools for Walkability: A Guide for Urban Analysts," Sustainability 2020, vol. 4405, 2020.

[22] R. Ewing and S. Handy, "Measuring the Unmeasurable: Urban Design Qualities Related to Walkability," Journal of Urban Design, vol. 14, pp. 65-84, 2009/02/01 2009.

[23] Google-Maps. Sattellite ma of the city of Mansoura [Online]. Available: https://www.google.com/maps/place/Mansoura,+Mansoura+Qism $+2,+\mathrm{M}$ ansoura,+Dakahlia+Governorate/@31.0413814,31.3478201,10745m/dat $\mathrm{a}=! 3 \mathrm{~m} 2 ! 1 \mathrm{e} 3 ! 4 \mathrm{~b} 1 ! 4 \mathrm{~m} 5 ! 3 \mathrm{~m} 4 ! 1 \mathrm{~s} 0 \times 14 \mathrm{f} 79 \mathrm{db} 7 \mathrm{a} 9053547: 0 \times f 8 d a b 3 \mathrm{bbed} 766 \mathrm{c}$ 97!8m2!3d31.0409483!4d31.3784704

\section{Title Arabic:}

$$
\text { إعادة تصور الثوارع: نهج تصميمي لتعزيز إمكانية المشي في القدانة }
$$

\section{Abstract Arabic:}

إن تصميم المدن لحركة الاليات و المركبات بدلاً من الناس قد حولها الى بيئات

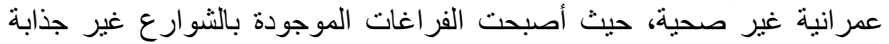

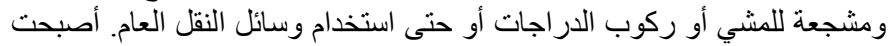

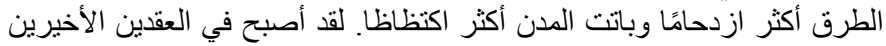

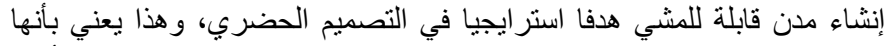

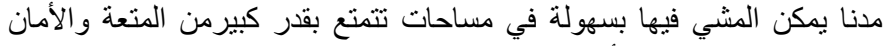

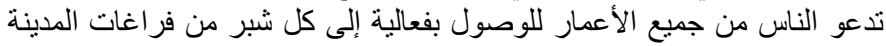

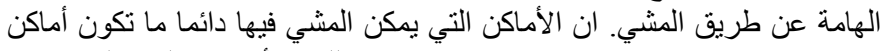

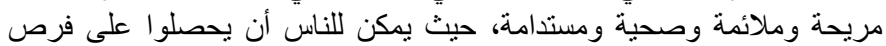

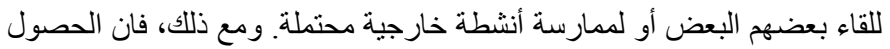

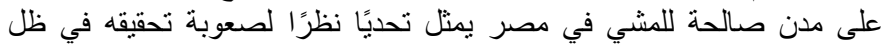

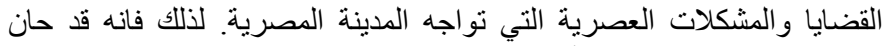

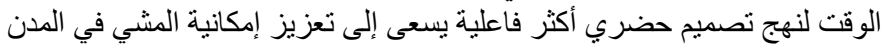

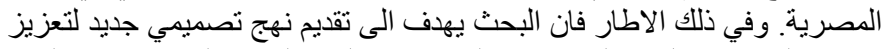

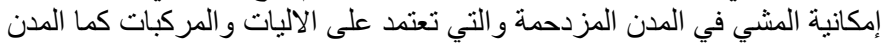

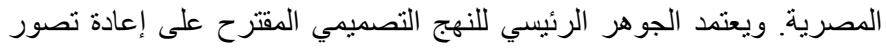

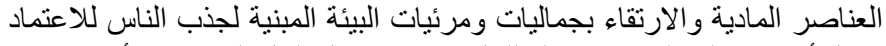
بشكل أساسي على المشي كوسيلة للنقل بجانب وسائل النقل الجماعي الأخرى. 